\title{
Cerebral astroblastoma radiologically mimicking pilocytic astrocytoma: A case report
}

\author{
Padam Joshi ${ }^{1}$, Sagar Pandey ${ }^{1}$, Usha Manandhar ${ }^{1}$, Saroj GC ${ }^{1}$, and Gopal Sedain ${ }^{2}$ \\ ${ }^{1}$ Tribhuvan University Institute of Medicine \\ ${ }^{2}$ Tribhuvan University Teaching Hospital
}

March 3, 2022

\begin{abstract}
Astroblastoma is a rare central nervous system tumor. We reported a case of a 24-years-old Nepalese woman with radiological features mimicking pilocytic astrocytoma which came out to be low grade astroblastoma in histopathological and immunohistochemistry examination after total excision of the tumor.
\end{abstract}

\section{Hosted file}

Astroblastoma manuscript; case report.docx available at https://authorea.com/users/463447/ articles/558537-cerebral-astroblastoma-radiologically-mimicking-pilocytic-astrocytoma-acase-report 